\title{
Inosine triphosphatase allele frequency and association with ribavirin-induced anaemia in Brazilian patients receiving antiviral therapy for chronic hepatitis $\mathrm{C}$
}

\author{
Nathália Delvaux', Vanessa Duarte da Costa', Maristella Matos da Costa', Livia Melo Villar', \\ Henrique Sérgio Moraes Coelho ${ }^{2}$, Eliane Bordalo Cathalá Esberard ${ }^{3}$, Priscila Pollo Flores ${ }^{3}$, \\ Carlos Eduardo Brandão-Mello ${ }^{4}$, Cristiane Alves Villela-Nogueira ${ }^{2}$, \\ Adilson José de Almeida ${ }^{1,4}$, Elisabeth Lampe ${ }^{1 /+}$
}

\author{
${ }^{1}$ Fundação Oswaldo Cruz, Instituto Oswaldo Cruz, Laboratório de Hepatites Virais, Rio de Janeiro, RJ, Brasil \\ ${ }^{2}$ Universidade Federal do Rio de Janeiro, Hospital Universitário Clementino Fraga Filho, Departamento de Hepatologia, Rio de Janeiro, \\ RJ, Brasil ${ }^{3}$ Universidade Federal Fluminense, Hospital Universitário Antônio Pedro, Departamento de Gastroenterologia, \\ Rio de Janeiro, RJ, Brasil ${ }^{4}$ Universidade Federal do Estado do Rio de Janeiro, Hospital Universitário Gaffrée e Guinle, \\ Departamento de Medicina Geral, Rio de Janeiro, RJ, Brasil
}

\begin{abstract}
Inosine triphosphatase (ITPA) single nucleotide polymorphisms (SNPS) are strongly associated with protection against ribavirin (RBV)-induced anaemia in European, American and Asian patients; however, there is a paucity of data for Brazilian patients. The aim of this study was to evaluate the ITPA SNP (rs7270101/rs1127354) frequency in healthy and hepatitis $C$ virus (HCV)-infected patients from Brazil and the association with the development of severe anaemia during antiviral therapy. ITPA SNPs were determined in $200 \mathrm{HCV}$ infected patients and 100 healthy individuals by sequencing. Biochemical parameters and haemoglobin $(\mathrm{Hb})$ levels were analysed in 97 patients who underwent antiviral therapy. A combination of AArs7270101+CCrs1127354 (100\% ITPase activity) was observed in 236/300 individuals. Anaemia was observed in $87.5 \%$ and $86.2 \%$ of treated patients with AA (rs 7270101$)$ and CC genotypes (rs1127354), respectively. Men with AA (rs7270101) showed a considerable reduction in Hb at week 12 compared to those with $A C / C C(p=0.1475)$. In women, there was no influence of genotype $(p=0.5295)$. For rs1127354, men with the CC genotype also showed a sudden reduction in Hb compared to those with AC. Allelic distribution of rs7270101 and rs1127354 shows high rates of the genotypes AA and CC, respectively, suggesting that the study population had a great propensity for developing RBV-induced anaemia. A progressive Hb reduction during treatment was observed; however, this reduction was greater in men at week 12 than in women.
\end{abstract}

Key words: ITPA - hepatitis C - ribavirin - anaemia - Brazil

Anaemia is a serious adverse effect of antiviral therapy with pegylated interferon (PEG-IFN) in combination with ribavirin (RBV) and it represents the main reason for RBV dose reduction, blood transfusion and even discontinuations of therapy (Fellay et al. 2010, Sung et al. 2011, Ahmed et al. 2013, Clark et al. 2013, Gara \& Ghany 2013). Haemolytic anaemia is also the most important haematologic adverse effect associated with triple therapy, with the incorporation of a new protease inhibitor into dual therapy with PEG-IFN/RBV (Hynicka \& Heil 2013, Romero-Gómez et al. 2013). Anaemia is presumably related to RBV use, as most patients show improved haemoglobin $(\mathrm{Hb})$ levels with the reduction of RBV dose, which is reversible after the end of treatment. Age, female gender, baseline levels of $\mathrm{Hb}$, creatinine

doi: 10.1590/0074-02760150104

Financial support: CNPq, FAPERJ, FIOCRUZ/IOC

+ Corresponding author: elampe@ioc.fiocruz.br

Received 15 March 2015

Accepted 8 June 2015 clearance and platelets were also reported to be factors that influenced RBV-induced anaemia (Ochi et al. 2010, Tsubota et al. 2012, Romero-Gómez et al. 2013).

Recent studies have shown that two single nucleotide polymorphisms (SNPs) in the inosine triphosphatase (ITPA) gene, located on chromosome 20, have been associated with protection against RBV-induced haemolytic anaemia: rs1127354 and rs7270101 (Fellay et al. 2010, Sakamoto et al. 2010, Rau et al. 2012). Both SNPs affect ITPA expression. Patients infected with hepatitis $\mathrm{C}$ virus (HCV) who carry the CC genotype at rs1127354 are more likely to develop anaemia than those who carry genotypes AC/AA, whereas at rs7270101 the reduction of $\mathrm{Hb}$ is greater in patients with the AA genotype than with the AC/CC genotype (Suzuki et al. 2011).

ITPA genotyping can help physicians make a treatment decision, especially when considering patients at high risk of developing haemolytic anaemia, such as those with advanced fibrosis and cirrhosis (Thompson et al. 2010, Romero-Gómez et al. 2013). Determination of ITPA polymorphisms might provide important contribution for the management of patients, especially those from different ethnicities, because the majority of research about this topic has been carried out in the United States of America (USA), Europe and Asia. Moreover, 
there is a scarcity of studies reporting the distribution of different genotypes of ITPA for Latin American populations, as well as the significance of ITPA variants in relation to RBV-induced anaemia. In Brazil, HCV infection is a serious public health concern, being a principal cause of death from complications of HCV-related chronic liver disease, such as cirrhosis and hepatocellular carcinoma (Alter et al. 1998, Gonçalves et al. 2013, Paranaguá-Vezozzo et al. 2014).

This study aims to evaluate ITPA polymorphism frequencies in healthy and $\mathrm{HCV}$-infected patients and the association of those with the development of anaemia in a cohort of patients with chronic HCV infection on antiviral therapy living in the state of Rio de Janeiro (RJ), Brazil.

\section{SUBJECTS, MATERIALS AND METHODS}

Patients and ethics - This study enrolled 200 patients with chronic HCV infection (72 males, aged 54.2 \pm 11.1 years) and 100 healthy individuals (34 males, aged 51.1 \pm 9.7 years) living in RJ between 2013-2014. Healthy individuals and patients with chronic $\mathrm{HCV}$ infection on antiviral therapy were prospectively evaluated on an outpatient basis at Gaffrée \& Guinle University Hospital, Clementino Fraga Filho University Hospital and Antônio Pedro University Hospital. A total of 97/200 patients who concluded antiviral therapy were investigated in relation to an association of ITPA polymorphisms with the development of anaemia. Patients were treated with PEG-IFN- $\alpha 2 b$, administered subcutaneously at a dose of $1.0-1.5 \mu \mathrm{g} / \mathrm{kg}$ weekly plus full-dose RBV (1,000-1,250 $\mathrm{mg} /$ day) for 24 (genotype 2 and 3 ) or 48 weeks (genotype 1). Haematological, biochemical and virological parameters at pretreatment (baseline) and at weeks 4, 8 and 12 were collected for comparative analysis. Drug dose reductions as a consequence of adverse effects were managed according to the severity of anaemia. Anaemia was considered as $\mathrm{Hb}$ levels $<10 \mathrm{~g} / \mathrm{dL}$ and/or a reduction $>$ $2 \mathrm{~g} / \mathrm{dL}$ in comparison to baseline. A sustained virologic response (SVR) was defined as undetectable HCV-RNA in serum samples 24 weeks after the end of therapy. This study was approved by the local ethics committee and conforms to the ethical guidelines of the 1975 Declaration of Helsinki. Each patient provided written informed consent before participating in this study.

Data collection and laboratory parameters - Information on demographics (gender and age) and HCV genotype were obtained at study entry. Biochemical markers of liver injury [alanine aminotransferase (ALT), aspartate aminotransferase (AST), gamma-glutamyl transpeptidase $(\gamma-\mathrm{GT})], \mathrm{Hb}$, platelet count (PLT), leukocytes count (LEUC) and viral load were obtained at baseline and at weeks 4, 8 and 12. Serum aminotransferases (ALT and AST) and $\gamma$-GT were measured with an automatic analyser (Labmax Plenno; Labtest, Brazil). Haematological parameters (Hb, PLT and LEUC) were assessed with an automated cell counter (ABX PENTRA 120; ABX Diagnostics, France).

Quantification of the HCV-RNA load and determinations of HCV genotypes were performed using the Abbott Real-Time HCV assay (Abbott Laboratories, USA), which has a dynamic range of detection between $12 \mathrm{IU} /$ $\mathrm{mL}(1.08 \log \mathrm{IU} / \mathrm{mL})$ and 100 million IU/mL ( $8.0 \log \mathrm{IU} /$ $\mathrm{mL})$, according to the manufacturer's instructions.

ITPA genotyping - Blood samples were collected into ethylenediamine tetraacetic acid tubes and human genomic DNA was extracted from $200 \mu \mathrm{L}$ whole blood using a QIAamp DNA Blood Kit (Qiagen, Germany) according to the manufacturer's directions. ITPAs variants (rs7270101 and rs1127354) were determined using direct sequencing after polymerase chain reaction (PCR) amplification. Specific primers used to target the two SNPs were: forward, 5'CGTGCTCACATGGAGAATCA3' and reverse, 5'CCT GGAAGCTACCTGGACAA3' (Cao \& Hegele 2002). The PCR products were purified using a QIAquick gel extraction kit (Qiagen) and submitted to nucleotide sequencing reactions in both directions using a BigDye Terminator kit 3.1 (Applied Biosystems, USA) according to the manufacturer's instructions and then analysed on an ABI 3730 DNA automated sequencer (Applied Biosystems).

Classification of predicted ITPase activity - ITPA deficiency phenotypes were classified according to the degree of predicted ITPA deficiency based on the compound genotype of rs1127354 and rs7270101, as previously determined by biochemical analyses: $100 \%\left(\mathrm{AA}_{\mathrm{rs} 7270101} \mathrm{CC}_{\mathrm{rs} 1127354}\right)$, $60 \%\left(\mathrm{AC}_{\mathrm{rs} 7270101} \mathrm{CC}_{\mathrm{rs} 1127354}\right), 30 \%\left(\mathrm{CC}_{\mathrm{rs} 7270101} \mathrm{CC}_{\mathrm{rs} 1127354}\right), 25 \%$ $\left(\mathrm{AA}_{\mathrm{rs} 7270101} \mathrm{AC}_{\mathrm{rs} 1127354}\right), 10 \%\left(\mathrm{AC}_{\mathrm{rs} 7270101} \mathrm{AC}_{\mathrm{rs} 1127354}\right)$ and $<5 \%$ $\left(\mathrm{AA}_{\mathrm{rs} 5270101} \mathrm{AA}_{\mathrm{rs}}^{\mathrm{rs} 12727354}\right)$ (Sumi et al. 2002, Maeda et al. 2005, Shipkova et al. 2006, Rembeck et al. 2014).

Statistical analysis - Data are expressed as frequencies and means \pm standard deviation for continuous variables with a normal distribution or median and ranges for those that did not pass the normality test (KolmogorovSmirnov test). Bivariate analysis was performed using the Pearson's chi-square test for independence to compare categorical variables. For continuous variables with a normal distribution, homoscedasticity was tested by the Levene's test and we used the unpaired Student's $t$ test to compare means (between 2 groups) or ANOVA with the Bonferroni posttest (for more than 2 groups). Continuous variables assumed not to follow a normal distribution were compared using the nonparametric Mann-Whitney $U$ test (between 2 groups) or the Friedman with Dunn posttest (for more than 2 groups) statistics to compare medians. Differences between groups were considered to be statistically significant at $\mathrm{p}<0.05$ (2-tailed). All calculations were performed using GraphPad InStat 1998, v.3.01 for Windows 95 (GraphPad Software, USA).

\section{RESULTS}

ITPA allele frequencies - Both healthy and HCVinfected patients groups did not differ significantly in relation to gender distribution (males, $34 \%$ vs. $38 \%$ ) or mean age $(51.0 \pm 9.7$ vs. $57.5 \pm 9.4)$. The ITPA allele frequencies of the 300 patients included in this study are shown in Table I. It was possible to observe that the allelic distribution of ITPA SNPs in both groups were similar $(\mathrm{rs} 7270101, \mathrm{p}=0.3614 ;$ rs1127354, $\mathrm{p}=0.6589)$.

In healthy individuals, AA and $\mathrm{CC}$ were the most prevalent genotypes at rs7270101 and rs1127354 SNPs 


\section{TABLE I}

Inosine triphosphatase (ITPA) alleles frequency in healthy patients $(\mathrm{n}=100)$ and patients infected with hepatitis $\mathrm{C}$ virus $(\mathrm{HCV})(\mathrm{n}=200)$

\begin{tabular}{|c|c|c|c|}
\hline \multicolumn{3}{|c|}{$\begin{array}{l}\text { ITPA } \\
\text { n (\%) }\end{array}$} & \multirow[b]{2}{*}{$\begin{array}{c}\text { Total } \\
(\mathrm{n}=300)\end{array}$} \\
\hline SNP & $\begin{array}{l}\text { Healthy group }^{a} \\
\quad(\mathrm{n}=100)\end{array}$ & $\begin{array}{l}\text { Infected with } \mathrm{HCV}^{a} \\
\qquad(\mathrm{n}=200)\end{array}$ & \\
\hline \multicolumn{4}{|c|}{ rs7270101 [n (\%)] } \\
\hline AA & $87(87)$ & $165(82.5)$ & $252(84)$ \\
\hline $\mathrm{AC}$ & $11(11)$ & $33(16.5)$ & 44 (14.7) \\
\hline $\mathrm{CC}$ & $2(2)$ & $2(1)$ & $4(1.3)$ \\
\hline \multicolumn{4}{|c|}{ rs1127354 [n (\%)] } \\
\hline $\mathrm{CC}$ & $93(93)$ & $190(95)$ & $283(94.3)$ \\
\hline $\mathrm{AC}$ & $7(7)$ & $10(5)$ & $17(5.7)$ \\
\hline AA & $0(0)$ & $0(0)$ & $0(0)$ \\
\hline
\end{tabular}

$a$ : $\mathrm{p}$ value was considered not significant $(<0.05)$; SNP: single nucleotide polymorphism.
(87\% and 93\%, respectively). Similarly, in patients infected with $\mathrm{HCV}$, these genotypes were also the most prevalent $(82.5 \%$ and $95 \%$, respectively).

Clinical and laboratory findings in treated patients with chronic HCV infection - The clinical and demographic characteristics of $\mathrm{HCV}$-infected patients treated with IFN/PEG-IFN plus RBV $(n=97)$ in this study are shown in Table II. Most patients were female (62\%), with a mean age of $57.5 \pm 9.4$ years (range $28-73$ years). Genotype determination in serum samples revealed that $\mathrm{HCV}$ genotypes $1,1 \mathrm{a}, 1 \mathrm{~b}$ and 3 were found in $16(16.5 \%), 30$ (31\%), $42(43.3 \%)$ and nine $(9.2 \%)$ patients, respectively. The median serum viral load measured was $825,046.0$ IU/mL (range 3,732.0-9,110,000.0 IU/mL). Overall, SVR was achieved in $32 \%$ of patients.

Biochemical and haematological data were analysed at baseline and after four, eight and 12 weeks of treatment. A significant and progressive reduction during antiviral treatment was observed for haematological $(\mathrm{Hb}$, PLT and LEUC) and biochemical (AST, ALT and $\gamma$-GT)

TABLE II

Clinical and demographic characteristics of hepatitis $\mathrm{C}$ virus (HCV)-infected patients treated with pegylated interferon plus ribavirin $(\mathrm{RBV})(\mathrm{n}=97)$

\begin{tabular}{|c|c|}
\hline Characteristics & Baseline values \\
\hline Age (years) (mean \pm SD) & $57.5 \pm 9.4$ \\
\hline \multicolumn{2}{|l|}{ Gender $[\mathrm{n}(\%)]$} \\
\hline Male & $37(38)$ \\
\hline Female & $60(62)$ \\
\hline $\mathrm{Hb}(\mathrm{g} / \mathrm{dL})($ mean $\pm \mathrm{SD})$ & $13.98 \pm 1.57$ \\
\hline Platelet count $\left(\times 10^{9} / \mathrm{L}\right)($ mean $\pm \mathrm{SD})$ & $168.5 \pm 67.5$ \\
\hline Leukocytes (x 109/L) [median (range)] & $5.5(5.6-14.1)$ \\
\hline $\operatorname{AST}^{a}(\mathrm{U} / \mathrm{L})[$ median (range) $]$ & $61.0(15.0-276.0)$ \\
\hline $\mathrm{ALT}^{b}(\mathrm{U} / \mathrm{L})[$ median (range)] & $75.0(12.0-281.0)$ \\
\hline$\gamma-\mathrm{GT}^{c}(\mathrm{U} / \mathrm{L})[$ median (range)] & $80.0(14.0-290.0)$ \\
\hline \multicolumn{2}{|l|}{$\mathrm{HCV}_{\text {genotype }}^{d}[\mathrm{n}(\%)]$} \\
\hline 1 & $16(16.5)$ \\
\hline 1a & $30(31)$ \\
\hline $1 b$ & $42(43.3)$ \\
\hline 3 & $9(9.2)$ \\
\hline \multicolumn{2}{|l|}{ Serum viral load $^{d}$} \\
\hline $\mathrm{UI} / \mathrm{mL}$ [median (range)] & $825,046.0(3,732.0-9,110,000.0)$ \\
\hline Log-transformed (mean $\pm \mathrm{SD}$ ) & $5.8 \pm 0.7$ \\
\hline \multicolumn{2}{|l|}{ RBV dose reduction ${ }^{e}[\mathrm{n}(\%)]$} \\
\hline Yes & $17(17.5)$ \\
\hline No & $31(32)$ \\
\hline \multicolumn{2}{|l|}{$\operatorname{SVR}^{f}[\mathrm{n}(\%)]$} \\
\hline Yes & $31(32)$ \\
\hline No & $35(36)$ \\
\hline
\end{tabular}

$a$ : aspartate aminotransferase (AST) normal values up to $37 \mathrm{U} / \mathrm{L} ; b$ : alanine aminotransferase (ALT) normal values up to $41 \mathrm{U} / \mathrm{L}$; $c$ : gamma glutamyl transpeptidase $(\gamma-\mathrm{GT}$ ) normal values between 11-50 U/L; $d$ : Abbott Real-Time HCV assay (Abbott Laboratories, USA) (lower detection limit: $12 \mathrm{IU} / \mathrm{mL}$ ); $e$ : at least $20 \%$ of RBV dose and therapy for $20 \%$ of the scheduled treatment period (data available from 48 patients); $f$ : data available from 66 patients; Hb: haemoglobin; SD: standard deviation; SVR: sustained virological response (undetectable serum HCV-RNA 24 weeks after completion of antiviral therapy). 


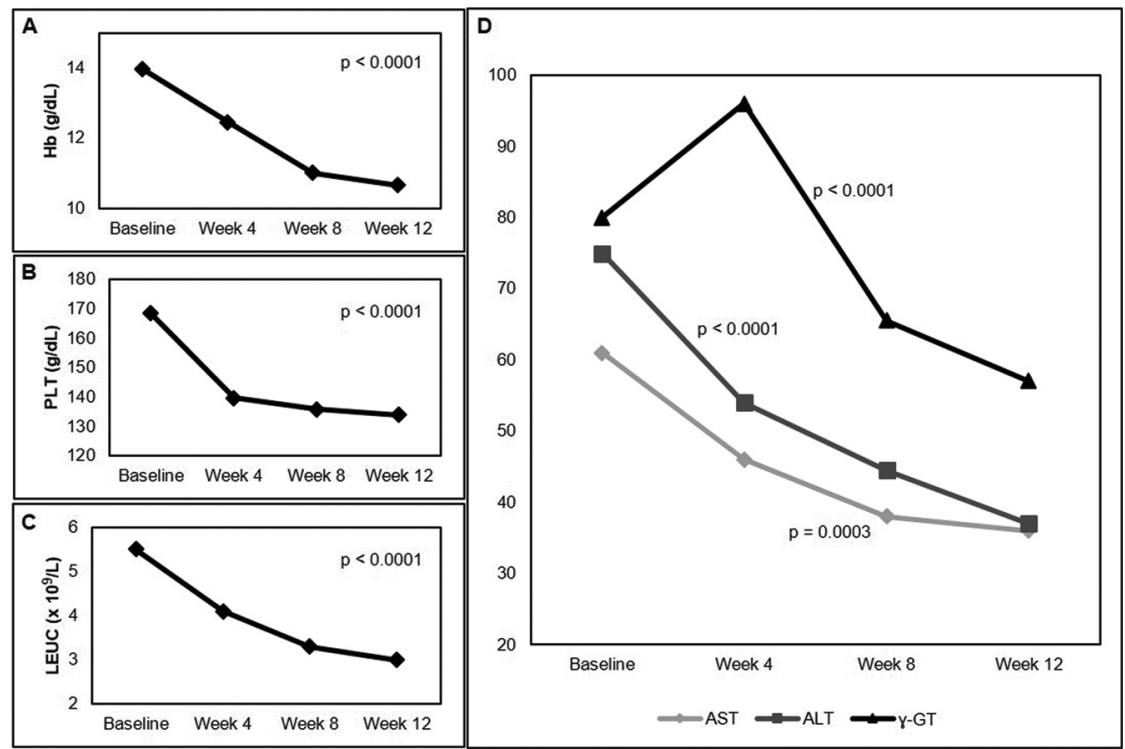

Fig. 1: biochemical and haematological data at baseline and at four, eight and 12 weeks of treatment. A progressive decline during antiviral treatment was observed in haematological parameters. A: haemoglobin (Hb); B: platelet (PLT); C: leukocytes count (LEUC); D: values for biochemical parameters. Aspartate aminotransferase (AST), alanine aminotransferase (ALT) and gamma-glutamyl transpeptidase ( $\gamma$-GT) showed a progressive decrease at baseline and throughout antiviral treatment.

parameters. The mean value of pretreatment $\mathrm{Hb}$ was $13.98 \pm 1.57 \mathrm{~g} / \mathrm{dL}$, with a significant reduction at week 4 $(12.46 \pm 1.56 \mathrm{~g} / \mathrm{dL})$, week $8(11.00 \pm 1.38 \mathrm{~g} / \mathrm{dL})$ and week $12(10.65 \pm 1.54 \mathrm{~g} / \mathrm{dL})$ after the start of antiviral treatment $(\mathrm{p}<0.0001)$ (Fig. 1A). RBV dose reductions were required in $17.5 \%$ of patients. Mean values of PLT counts were $168.5 \pm 67.5 \times 10^{9} / \mathrm{L}, 139.6 \pm 55.2 \times 10^{9} / \mathrm{L}, 135.8$ $\pm 65.1 \times 10^{9} / \mathrm{L}$ and $133.9 \pm 60.7 \times 10^{9} / \mathrm{L}$ at baseline and after four, eight and 12 weeks of treatment, respectively $(\mathrm{p}<0.0001)$ (Fig. 1B). Median values of LEUC were 5.5 $\times 10^{9} / \mathrm{L}$ (range 5.6-14.1 $\times 10^{9} / \mathrm{L}$ ), $4.1 \times 10^{9} / \mathrm{L}($ range 3.6$13.0 \times 10^{9} / \mathrm{L}$ ), $3.3 \times 10^{9} / \mathrm{L}\left(\right.$ range $1.1-7.5 \times 10^{9} / \mathrm{L}$ ) and 3.0 $\times 10^{9} / \mathrm{L}\left(\right.$ range $\left.1.0-11.0 \times 10^{9} / \mathrm{L}\right)$ at baseline and after four, eight and 12 weeks, respectively $(\mathrm{p}<0.0001)$ (Fig. 1C).

In relation to biochemical parameters, median AST values were $61.0 \mathrm{U} / \mathrm{L}$ (range 15.0-276.0 U/L), 46.0 U/L (range 23.0-190.0 U/L), 38.0 U/L (range 20.0-158.0 U/L) and $36.0 \mathrm{U} / \mathrm{L}$ (range $10.0-121.0 \mathrm{U} / \mathrm{L}$ ) at baseline and at week 4,8 and 12 , respectively $(\mathrm{p}<0.0001)$. Median ALT values were $75.0 \mathrm{U} / \mathrm{L}$ (range 12.0-281.0 U/L), 54.0 U/L (range 19.0-209.0 U/L), 44.5 U/L (range 9.0-240.0 U/L) and $37.0 \mathrm{U} / \mathrm{L}$ (range $9.0-150.0 \mathrm{U} / \mathrm{L}$ ) at baseline and at week 4,8 and 12 , respectively $(\mathrm{p}<0.0001)$. Median $\gamma$-GT values at baseline and at week 4, 8 and 12 were as follows: 80.0 $\mathrm{U} / \mathrm{L}$ (range 14.0-290.0 U/L), 96.0 U/L (range 19.3-252.0 $\mathrm{U} / \mathrm{L}$ ), 65.5 U/L (range 15.0-334.0 U/L) and 57.0 U/L (range 13.0-563.0 U/L), respectively $(\mathrm{p}=0.0003)$ (Fig. 1D).

ITPA alleles and development of anaemia in $\mathrm{HCV}$ treated patients - In treated patients with chronic HCV infection $(\mathrm{n}=97)$, the AA genotype of rs7270101 SNP was observed in $80(83 \%)$ of patients whereas the $\mathrm{AC} / \mathrm{CC}$ genotype was detected in $17(17 \%)$ patients. At rs 1127354 , the CC genotype was found in 94 (97\%) patients and the AC genotype occurred in three (3\%) patients.
Table III shows the ITPA allele frequencies in relation to demographics and $\mathrm{Hb}$ levels at baseline and at week 4,8 and 12 after starting antiviral treatment. Of the 80 patients with the AA genotype at rs 7270101 , anaemia was observed in $70(87.5 \%)$ patients and $12(70.6 \%)$ of the 17 patients with genotype $\mathrm{AC} / \mathrm{CC}$ developed anaemia. At rs1127354, most patients who developed anaemia showed the CC genotype (86.2\%). The allelic distributions of both SNPs were categorised according to gender and we observed that from the 26 males who developed anaemia, genotype AA at rs 7270101 was detected in 21 $(80.7 \%)$ individuals. For rs1127354, all males with anaemia presented the $\mathrm{CC}$ genotype.

A progressive reduction in $\mathrm{Hb}$ levels was observed at baseline and throughout antiviral treatment (at week 4,8 and 12), but the $\mathrm{Hb}$ reduction at week 12 was relatively higher in individuals with an AA genotype (rs7270101) and/or a CC genotype (rs1127354). The distribution of ITPA genotypes according to gender revealed that men who carried the AA genotype (rs7270101) had a slightly greater reduction in $\mathrm{Hb}$ than women. Fig. 2 shows the reduction in $\mathrm{Hb}$ values compared with baseline at week 12 of treatment according to the ITPA genotypes. The distribution of the predicted ITPase activity according to compound genotype of rs7270101 and rs1127354, as previously determined by biochemical analyses, is shown in Table IV. The combination $\mathrm{AA}_{\mathrm{rs} 7270101} \mathrm{CC}_{\mathrm{rs} 1127354}$ that yields $100 \%$ predicted ITPase activity was observed in 236/300 individuals (78.7\%) of the present study cohort and the genotype combination that presented predicted ITPase activity equal to or below $30 \%$ was observed in only 21 individuals.

The relationship between ITPA genotypes and SVR demonstrated that SVR could be observed in $49 \%$ (27/55) of patients with the AA genotype and in 36\% 


\section{TABLE III}

Inosine triphosphatase (ITPA) alleles frequencies in relation to demographics and haemoglobin $(\mathrm{Hb})$ levels during treatment in hepatitis $\mathrm{C}$ virus $(\mathrm{HCV})$ patients $(\mathrm{n}=97)$

\begin{tabular}{|c|c|c|c|c|}
\hline & \multicolumn{4}{|c|}{ ITPA SNPs } \\
\hline & \multicolumn{2}{|c|}{ rs7270101 } & \multicolumn{2}{|c|}{ rs1127354 } \\
\hline & AA & $\mathrm{AC} / \mathrm{CC}$ & $\mathrm{CC}$ & $\mathrm{AC}$ \\
\hline \multicolumn{5}{|l|}{ Anemia $^{a}[\mathrm{n}(\%)]$} \\
\hline Yes & $70(87.5)$ & $12(70.6)$ & $81(86.2)$ & $1(33.3)$ \\
\hline No & $10(12.5)$ & $5(29.4)$ & $13(13.8)$ & $2(66.7)$ \\
\hline \multicolumn{5}{|l|}{$\operatorname{Gender}^{b}[\mathrm{n}(\%)]$} \\
\hline Male with anaemia & $21(80.7)$ & $5(19.3)$ & $26(100)$ & $0(0)$ \\
\hline Female with anaemia & $49(87.5)$ & $7(12.5)$ & $55(98.2)$ & $1(1.8)$ \\
\hline \multicolumn{5}{|l|}{$\mathrm{Hb}$ at baseline (mean $\pm \mathrm{SD}$ ) } \\
\hline Male & $14.4 \pm 2.3$ & $14.9 \pm 1.0$ & $14.5 \pm 2.1$ & $14.9 \pm 0.9$ \\
\hline Female & $13.6 \pm 1.0$ & $13.5 \pm 0,7$ & $13.6 \pm 0.9$ & $12.9 \pm 0.0$ \\
\hline \multicolumn{5}{|l|}{$\mathrm{Hb}$ at week $4($ mean $\pm \mathrm{SD})$} \\
\hline Male & $12.8 \pm 1.4$ & $13.6 \pm 0.9$ & $12.6 \pm 1.5$ & $16.0 \pm 0.0$ \\
\hline Female & $12.0 \pm 1.6$ & $12.5 \pm 0.9$ & $12.0 \pm 1.5$ & $13.0 \pm 0.0$ \\
\hline \multicolumn{5}{|l|}{$\mathrm{Hb}$ at week $8($ mean $\pm \mathrm{SD})$} \\
\hline Male & $11.4 \pm 1.4$ & $11.9 \pm 1.0$ & $11.3 \pm 1.1$ & $15.0 \pm 0.7$ \\
\hline Female & $10.6 \pm 1.2$ & $10.8 \pm 1.7$ & $10.7 \pm 1.2$ & $9.0 \pm 0.0$ \\
\hline \multicolumn{5}{|l|}{$\mathrm{Hb}$ at week $12($ mean $\pm \mathrm{SD})$} \\
\hline Male & $10.9 \pm 1.9$ & $12.0 \pm 1.6$ & $10.9 \pm 1.8$ & $14.2 \pm 0.9$ \\
\hline Female & $10.3 \pm 1.1$ & $10.5 \pm 1.3$ & $10.3 \pm 1.0$ & $7.0 \pm 0.0$ \\
\hline
\end{tabular}

$a$ : defined as Hb levels $<10 \mathrm{~g} / \mathrm{dL}$ and/or decline $>2 \mathrm{~g} / \mathrm{dL} ; b$ : male $=37$, female $=60$; SD: standard deviation; SNP: single nucleotide polymorphisms.

(4/11) of patients with the AC genotype (rs7270101). For rs1127354, differences between the distributions of genotypes in relation to SVR were not possible to analyse because almost all treated patients (94/97) with chronic $\mathrm{HCV}$ infection carried the CC genotype.

\section{DISCUSSION}

Recently, genome-wide association studies identified polymorphisms in the ITPA gene in patients with chronic hepatitis $\mathrm{C}$ who received PEG-IFN/RBV. These studies have demonstrated a strong association with SNPs rs7270101 and rs1127354 and RBV-induced haemolytic anaemia, which have led to a better understanding of the effects of RBV-induced anaemia (Fellay et al. 2010, Sakamoto et al. 2010, Thompson et al. 2010, Kurosaki et al. 2011, Seto et al. 2011, Tanaka et al. 2011).

The ITPA gene encodes the enzyme ITPA (ITPase) which catalyses the conversion of inosine triphosphate (ITP) to inosine monophosphate and pyrophosphate so that ITP does not accumulate in normal cells. ITP is used to maintain the red blood cell (RBC) adenosine triphosphate pool, thus preventing oxidative stress, which is thought to be a critical mediator of RBV-induced haemolysis (Hitomi et al. 2011). Deficiency of ITPase disrupts this cycle, resulting in an accumulation of ITP (Maeda et al. 2005).

RBV (1- $\beta$-D-ribofuranosyl-1H-1,2,4-triazole-3carboxamide) is a synthetic nucleoside analogue that has actions in vitro against a broad range of viruses (Patterson \& Fernandez-Larsson 1990) and has been used in combination with IFN during antiviral treatment. RBV can be incorporated into erythrocytes, where it undergoes phosphorylation to its pharmacologically active forms through adenosine kinase. The RBV triphosphate conjugates cannot cross the erythrocyte cell membrane and accumulate in the intracellular compartment, causing oxidative damage and leading to haemolysis (Kowdley 2005). ITPase deficiency causes an accumulation of ITP in RBCs and may compete with RBV triphosphate, thereby protecting from RBVinduced haemolysis (Fraser et al. 1975, Shipkova et al. 2006, Sakamoto et al. 2010, Kim et al. 2013).

To the best of our knowledge, this is the first report of the frequency of ITPA gene polymorphisms in a cohort of Brazilian healthy individuals and patients infected with HCV. The overall frequency $(n=300)$ of allelic distribution at rs7270101 and rs1127354 shows high rates of the genotypes AA (84\%) and CC (94.3\%), respectively. These frequencies were different from those reported by Fellay et al. (2010) who showed that $48.4 \%$ of American individuals carried the AA genotype (rs7270101) and 47.6\% had the CC genotype (rs1127354). By contrast, European studies demonstrate that the majority of individuals carry AA and CC genotypes for rs7270101 and rs1127354, respectively (Domingo et al. 2012, D'Avolio 

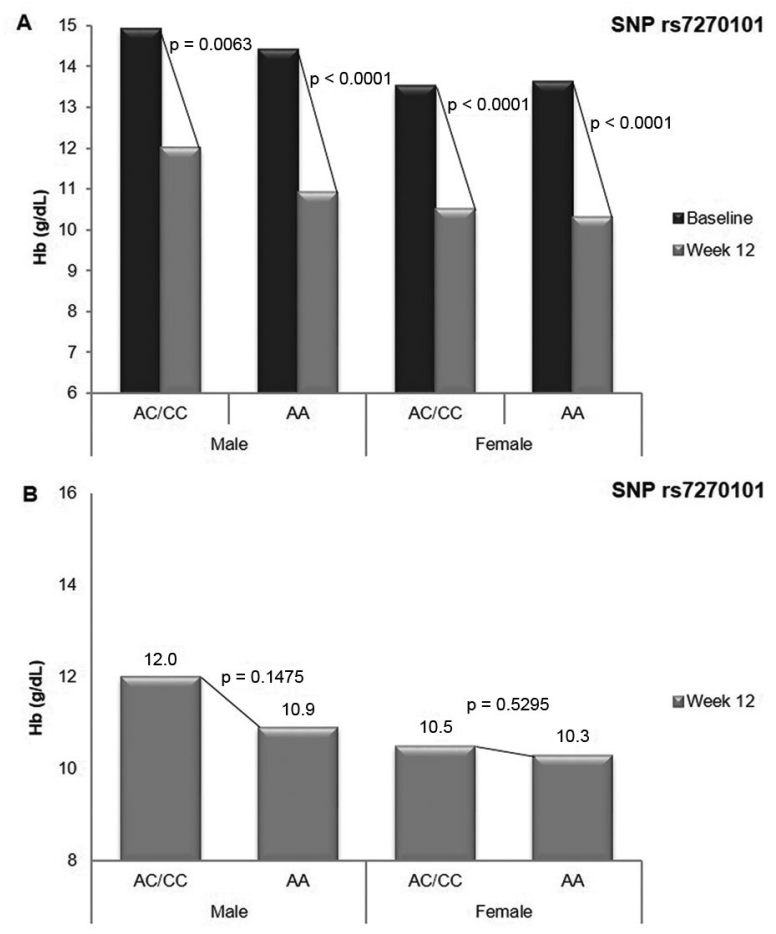

Fig. 2: haemoglobin (Hb) declines at variant rs7270101 single nucleotide polymorphisms (SNP) according to gender. A: comparison of $\mathrm{Hb}$ levels between week 12 of antiviral treatment and baseline for both genders. Sizable declines are observed; B: gender differences of $\mathrm{Hb}$ levels at week 12. Men who carried the AA genotype are seen to exhibit a slightly greater $\mathrm{Hb}$ decline than women.

\section{TABLE IV}

Distribution of predicted ITPase activity according to compound genotype of rs7270101 and rs1127354 as previously determined by biochemical analyses and in our study population $(n=300)$

\begin{tabular}{lccc}
\hline & & $\begin{array}{c}\text { Predicted } \\
\text { ITPase activity } \\
\text { rs7270101 }\end{array}$ & $\begin{array}{c}\text { Present } \\
\text { study population } \\
\text { n }(\%)\end{array}$ \\
\hline AA & rs1127354 & 100 & $236(78.7)$ \\
AC & CC & 60 & $43(14.3)$ \\
CC & CC & 30 & $4(1.3)$ \\
AA & AC & 25 & $16(5.3)$ \\
AC & AC & 10 & $1(0.3)$ \\
AA & AA & $<5$ & $0(0)$
\end{tabular}

a: Sumi et al. (2002), Maeda et al. (2005), Shipkova et al. (2006) and Rembeck et al. (t2014).

et al. 2012, Naggie et al. 2012, Rau et al. 2013). Among Japanese and Korean populations, the CC genotype is also more prevalent at rs1127354, but they are monoallelic for the rs7270101 AA genotype (Ochi et al. 2010, Tanaka et al. 2011, Kim et al. 2013). Although the Brazilian population is known to have a strong miscegenation as a consequence of different migration flows, the al- lelic distribution of both SNPs in our population showed greater similarity to Caucasian populations, although the proportion of alleles associated with anaemia was slightly higher in the Brazilian population.

In this present study, anaemia was more often observed in patients presenting ITPA genotypes that were recognised as predictors of RBV-haemolytic anaemia, in accordance with studies conducted in the USA (Fellay et al. 2010, Thompson et al. 2010), Europe (D'Avolio et al. 2012, Naggie et al. 2012, Rau et al. 2013) and Asia (Ochi et al. 2010, Sakamoto et al. 2010, Suzuki et al. 2011, Kim et al. 2013, Kurosaki et al. 2013). Nevertheless, the frequency of the allelic distribution of both SNPs was slightly higher than that reported in the studies mentioned above, suggesting that our population is more prone to develop anaemia.

A progressive reduction in $\mathrm{Hb}$, particularly at week 12 of dual therapy with PEG-IFN/RBV, was observed in this study. Anaemia, defined as $\mathrm{Hb}$ levels $<10 \mathrm{~g} /$ $\mathrm{dL}$ and/or a reduction greater than $2 \mathrm{~g} / \mathrm{dL}$ compared to baseline, was higher in genotypes AA (rs7270101) and CC (rs1127354) in both genders. We could observe a significant difference in the reduction in $\mathrm{Hb}$ up to week 12 associated with gender. For rs7270101, males who had an AA genotype showed an evident, but not statistically significant reduction $(\mathrm{p}=0.1475)$ in $\mathrm{Hb}$ at week 12 compared to those who had the AC/CC genotype. By contrast, there was no influence of the ITPA genotype on $\mathrm{Hb}$ levels among female patients because the reduction was similar to that of patients who had an $\mathrm{AA}$ or $\mathrm{AC} /$ CC genotype $(p=0.5295)$ (Fig. 2). For rs1127354, males who had a CC genotype also showed a more evident reduction in $\mathrm{Hb}$ when compared to those who had the AC genotype. This present study is the first to explore gender differences as possible protective cofactors from RBV-haemolytic anaemia in relation to ITPA allele distributions and $\mathrm{Hb}$ reductions during treatment. Scherzer et al. (2013) detected gender differences in the incidence of RBV-haemolytic anaemia at week 4 in Austrian patients treated with PEG-IFN/RBV. According to those authors, $\mathrm{Hb}$ reductions were smaller in females than in males and among premenopausal females compared with postmenopausal patients. However, these differences not considered to be related to ITPA alleles at rs1127354 or rs7270101 (Scherzer et al. 2013).

The distribution of predicted ITPase activity according to the genotype at rs7270101 and rs1127354 indicated that most (78.7\%) of our population exhibited $100 \%$ of predicted ITPase activity. Only a small number of patients $(7 \%)$ presented ITPase activity equal to or below $30 \%$. ITPase activity is known to increase the probability of the development of anaemia. Additionally, most patients in our cohort exhibited the worst combination for both SNPs $\left(\mathrm{AA}_{\mathrm{rs} 7270101} \mathrm{CC}_{\mathrm{rs} 1127354}\right.$ and $\mathrm{AC}_{\mathrm{rs} 7270101}$ $\mathrm{CC}_{\mathrm{r} s 127354}$ ), which could explain why so many Brazilian patients developed RBV-induced anaemia.

Concerning ITPA polymorphisms studied in this present work and in response to antiviral treatment, no association was detected between the SVR and ITPA genotypes. Therefore, our findings are in accord with several other studies (Thompson et al. 2010, Motomura et al. 2012, Naggie et al. 2012, Kim et al. 2013). More- 
over, almost all treated patients with chronic HCV infection were monoallelic for the rs1127354 CC genotype.

The main limitation of this present study was the relatively small sample size, although we included all patients $(\mathrm{n}=97)$ who presented complete data on biochemical and haematological parameters (at baseline and weeks 4, 8 and 12) and had completed PEG-IFN/ RBV antiviral therapy during the study period.

In conclusion, the allelic distribution frequency of SNPs in rs7270101 and rs1127354 showed high rates of the genotypes AA and $\mathrm{CC}$, respectively, suggesting that the study population had a great propensity for developing RBV-induced anaemia. A progressive reduction in $\mathrm{Hb}$ during the weeks of $\mathrm{HCV}$ treatment based on PEG-IFN/RBV was observed in this study, however, the reduction in $\mathrm{Hb}$ levels at week 12 in male patients was greater than that observed among females.

\section{ACKNOWLEDGEMENTS}

To Geane Lopes Flores, Islene Azevedo, Letícia de Paula Scalioni, Moyra Machado Portilho and Selma Xavier Silva Lima Pinheiro, for technical assistance in collecting blood samples.

\section{REFERENCES}

Ahmed WH, Furusyo N, Zaky S, Eldin AS, Aboalam H, Ogawa E, Murata M, Hayashi J 2013. Pre-treatment role of inosine triphosphate pyrophosphatase polymorphism for predicting anemia in Egyptian hepatitis C virus patients. World J Gastroenterol 19: 1387-1395.

Alter MJ, Mast EE, Moyer LA, Margolis HS 1998. Hepatitis C. Infect Dis Clin North Am 12: 13-26.

Cao H, Hegele RA 2002. DNA polymorphisms in ITPA including basis of inosine triphosphatase deficiency. J Hum Genet 47: 620-622.

Clark PJ, Aghemo A, Degasperi E, Galmozzi E, Urban TJ, Vock DM, Patel K, Thompson AJ, Rumi MG, D’Ambrosio R, Muir AJ, Colombo M 2013. Inosine triphosphatase deficiency helps predict anaemia, anaemia management and response in chronic hepatitis C therapy. J Viral Hepat 20: 858-866.

D’Avolio A, Ciancio A, Siccardi M, Smedile A, Baietto L, Simiele M, Marucco DA, Cariti G, Calcagno A, de Requena DG, Sciandra M, Cusato J, Troshina G, Bonora S, Rizzetto M, Di Perri G 2012. Inosine triphosphatase polymorphisms and ribavirin pharmacokinetics as determinants of ribavirinassociate anemia in patients receiving standard anti-HCV treatment. Ther Drug Monit 34: 165-170.

Domingo P, Guardiola JM, Salazar J, Torres F, Mateo MG, Pacho C, Del Mar Gutierrez M, Lamarca K, Fontanet A, Martin J, Muñoz J, Vidal F, Baiget M 2012. Association of ITPA gene polymorphisms and the risk of ribavirin-induced anemia in HIV/hepatitis $\mathrm{C}$ virus (HCV)-coinfected patients receiving $\mathrm{HCV}$ combination therapy. Antimicrob Agents Chemother 56: 2987-2993.

Fellay J, Thompson AJ, Ge D, Gumbs CE, Urban TJ, Shianna KV, Little LD, Qiu P, Bertelsen AH, Watson M, Warner A, Muir AJ, Brass C, Albrecht J, Sulkowski M, McHutchison JG, Goldstein DB 2010. ITPA gene variants protect against anaemia in patients treated for chronic hepatitis C. Nature 464: 405-408.

Fraser JH, Meyers H, Henderson JF, Brox LW, McCoy EE 1975. Individual variation in inosine triphosphate accumulation in human erythrocytes. Clin Biochem 8: 353-364.

Gara N, Ghany MG 2013. What the infectious disease physician needs to know about pegylated interferon and ribavirin. Clin Infect Dis 56: $1629-1636$.

Gonçalves PL, Zago-Gomes M da P, Marques CC, Mendonça AT, Gonçalves CS, Pereira FE 2013. Etiology of liver cirrhosis in Brazil: chronic alcoholism and hepatitis viruses in liver cirrhosis diagnosed in the state of Espírito Santo. Clinics (Sao Paulo) 68: 291-295.

Hitomi Y, Cirulli ET, Fellay J, McHutchison JG, Thompson AJ, Gumbs CE, Shianna KV, Urban TJ, Goldstein DB 2011. Inosine triphosphate protects against ribavirin-induced adenosine triphosphate loss by adenylosuccinate synthase function. Gastroenterology 140: 1314-1321.

Hynicka LM, Heil EL 2013. Anemia management in patients with chronic viral hepatitis C. Ann Pharmacother 47: 228-236.

Kim JS, Ahn SM, Jung YK, Kwon OS, Kim YS, Choi DJ, Kim JH 2013. The impact of inosine triphosphatase variants on hemoglobin level and sustained virologic response of chronic hepatitis $\mathrm{C}$ in Korean. J Korean Med Sci 28: 1213-1219.

Kowdley KV 2005. Hematologic side effects of interferon and ribavirin therapy. J Clin Gastroenterol 39 (Suppl. 1): 3-8.

Kurosaki M, Tanaka Y, Nishida N, Sakamoto N, Enomoto N, Matsuura K, Asahina Y, Nakagawa M, Watanabe M, Sakamoto M, Maekawa S, Tokunaga K, Mizokami M, Izumi N 2013. Model incorporating the ITPA genotype identifies patients at high risk of anemia and treatment failure with pegylated interferon plus ribavirin therapy for chronic hepatitis C. J Med Virol 85: 449-458.

Kurosaki M, Tanaka Y, Tanaka K, Suzuki Y, Hoshioka Y, Tamaki N, Kato T, Yasui Y, Hosokawa T, Ueda K, Tsuchiya K, Kuzuya T, Nakanishi H, Itakura J, Takahashi Y, Asahina Y, Matsuura K, Sugauchi F, Enomoto N, Nishida N, Tokunaga K, Mizokami M, Izumi N 2011. Relationship between genetic polymorphisms of the inosine triphosphatase gene and anemia or outcome after treatment with pegylated-interferon and ribavirin. Antivir Ther 16: 685-694.

Maeda T, Sumi S, Ueta A, Ohkubo Y, Ito T, Marinaki AM, Kurono Y, Hasegawa S, Togari H 2005. Genetic basis of inosine triphosphate pyrophosphohydrolase deficiency in the Japanese population. Mol Genet Metab 85: 271-279.

Motomura T, Koga E, Taketomi A, Fukuhara T, Mano Y, Muto J, Konishi H, Toshima T, Uchiyama H, Yoshizumi T, Shirabe K, Maehara Y 2012. Efficacy of splenectomy in preventing anemia in patients with recurrent hepatitis $\mathrm{C}$ following liver transplantation is not dependent on inosine triphosphate pyrophosphatase genotype. Hepatol Res 42: 288-295.

Naggie S, Rallon NI, Benito JM, Morello J, Rodriguez-Novoa S, Clark PJ, Thompson AJ, Shianna KV, Vispo E, McHutchison JG, Goldstein DB, Soriano V 2012. Variants in the ITPA gene protect against ribavirin-induced hemolytic anemia in $\mathrm{HIV} / \mathrm{HCV}$-coinfected patients with all HCV genotypes. J Infect Dis 205: 376-383.

Ochi H, Maekawa T, Abe H, Hayashida Y, Nakano R, Kubo M, Tsunoda T, Hayes CN, Kumada H, Nakamura Y, Chayama K 2010. ITPA polymorphism affects ribavirin-induced anemia and outcome of therapy - a genome-wide study of Japanese HCV patients. Gastroenterology 139: 1190-1197.

Paranaguá-Vezozzo DC, Ono SK, Alvarado-Mora MV, Farias AQ, Cunha-Silva M, França JI, Alves VA, Sherman M, Carrilho FJ 2014. Epidemiology of HCC in Brazil: incidence and risk factors in a ten-year cohort. Ann Hepatol 13: 386-393.

Patterson JL, Fernandez-Larsson R 1990. Molecular mechanisms of action of ribavirin. Rev Infect Dis 12: 1139-1146.

Rau M, Stickel F, Russmann S, Manser CN, Becker PP, Weisskopf M, Schmitt J, Dill MT, Dufour JF, Moradpour D, Semela D, Müllhaupt B, Geier A, Swiss Hepatitis C Cohort Study Group (SCCS) 2013. Impact of genetic SLC28 transporter and ITPA variants on ribavirin serum level, hemoglobin drop and therapeutic response in patients with HCV infection. J Hepatol 58: 669-675.

Rau M, Baur K, Geier A 2012. Host genetic variants in the pathogenesis of hepatitis C. Viruses 4: 3281-3302. 
Rembeck K, Waldenström J, Hellstrand K, Nilsson S, Nyström K, Martner A, Lindh M, Norkrans G, Westin J, Pedersen C, Färkkilä M, Langeland N, Buhl MR, Mørch K, Christensen PB, Lagging M 2014. Variants of the inosine triphosphate pyrophosphatase gene are associated with reduced relapse risk following treatment for HCV genotype 2/3. Hepatology 59: 2131-2139.

Romero-Gómez M, Berenguer M, Molina E, Calleja JL 2013. Management of anemia induced by triple therapy in patients with chronic hepatitis $\mathrm{C}$ : challenges, opportunities and recommendations. J Hepatol 59: 1323-1330.

Sakamoto N, Tanaka Y, Nakagawa M, Yatsuhashi H, Nishiguchi S, Enomoto N, Azuma S, Nishimura-Sakurai Y, Kakinuma S, Nishida N, Tokunaga K, Honda M, Ito K, Mizokami M, Watanabe M 2010. ITPA gene variant protects against anemia induced by pegylated interferon- $\alpha$ and ribavirin therapy for Japanese patients with chronic hepatitis C. Hepatol Res. 40: 1063-1071.

Scherzer TM, Stättermayer AF, Stauber R, Maieron A, Strasser M, Laferl H, Schwarzer R, Datz C, Rutter K, Beinhardt S, SteindlMunda P, Hofer H, Ferenci P 2013. Effect of gender and ITPA polymorphisms on ribavirin induced anemia in chronic hepatitis C patients. J Hepatol 59: 964-971.

Seto WK, Tanaka Y, Liu K, Lai CL, Yuen MF 2011. The effects of IL$28 \mathrm{~B}$ and ITPA polymorphisms on treatment of hepatitis $\mathrm{C}$ virus genotype 6. Am J Gastroenterol 106: 1007-1008.

Shipkova M, Lorenz K, Oellerich M, Wieland E, von Ahsen N 2006. Measurement of erythrocyte inosine triphosphate pyrophosphohydrolase (ITPA) activity by HPLC and correlation of ITPA genotypephenotype in a Caucasian population. Clin Chem 52: 240-247.
Sumi S, Marinaki AM, Arenas M, Fairbanks L, Shobowale-Bakre M, Rees DC, Thein SL, Ansari A, Sanderson J, de Abreu RA, Simmonds HA, Duley JA 2002. Genetic basis of inosine triphosphate pyrophosphohydrolase deficiency. Human Genetics 111: 360-367.

Sung H, Chang M, Saab S 2011. Management of hepatitis C antiviral therapy adverse effects. Curr Hepat Rep 10: 33-40.

Suzuki F, Suzuki Y, Akuta N, Sezaki H, Hirakawa M, Kawamura Y, Hosaka T, Kobayashi M, Saito S, Arase Y, Ikeda K, Kobayashi M, Chayama K, Kamatani N, Nakamura Y, Miyakawa Y, Kumada $\mathrm{H}$ 2011. Influence of ITPA polymorphisms on decreases of hemoglobin during treatment with pegylated interferon, ribavirin and telaprevir. Hepatology 53: 415-421.

Tanaka Y, Kurosaki M, Nishida N, Sugiyama M, Matsuura K, Sakamoto N, Enomoto N, Yatsuhashi H, Nishiguchi S, Hino K, Hige S, Itoh Y, Tanaka E, Mochida S, Honda M, Hiasa Y, Koike A, Sugauchi F, Kaneko S, Izumi N, Tokunaga K, Mizokami M 2011. Genome-wide association study identified ITPA/DDRGK1 variants reflecting thrombocytopenia in pegylated interferon and ribavirin therapy for chronic hepatitis C. Hum Mol Genet 20: 3507-3516.

Thompson AJ, Fellay J, Patel K, Tillmann HL, Naggie S, Ge D, Urban TJ, Shianna KV, Muir AJ, Fried MW, Afdhal NH, Goldstein DB, McHutchison JG 2010. Variants in the ITPA gene protect against ribavirin-induced hemolytic anemia and decrease the need for ribavirin dose reduction. Gastroenterology 139: 1181-1189.

Tsubota A, Shimada N, Abe H, Yoshizawa K, Agata R, Yumoto Y, Ika M, Namiki Y, Nagatsuma K, Matsudaira H, Fujise K, Tada N, Aizawa Y 2012. Several factors including ITPA polymorphism influence ribavirin-induced anemia in chronic hepatitis C. World J Gastroenterol 18: 5879-5888. 